ROCZNIK ADMINISTRACJI PUBLICZNEJ 2020 (6)

ARTYKULY / ARTICLES

Administracyjne prawo ustrojowe

Administrative systemic law

PaWet OSTACHOWSKI ${ }^{1}$

\title{
Funkcjonowanie i wyzwania władz lokalnych związane z budżetem partycypacyjnym w Polsce na przykładzie największych miast
}

\section{Wprowadzenie}

Od wielu już lat $\mathrm{w}$ funkcjonowanie przestrzeni miejskiej $\mathrm{w}$ Polsce oraz klimat lokalnej współpracy władz samorządowych z mieszkańcami coraz mocniej wrasta budżet partycypacyjny, zwany też obywatelskim. Początkowo obecny tylko w dużych miastach, staje się on narzędziem uczącym mieszkańców sztuki współpracy, uzgadniania sprzecznych stanowisk i postrzegania świata wokół nie tylko indywidualistycznie. Wymaga od nich zrozumienia istnienia wspólnych potrzeb oraz problemów, których władze miejskie, nie potrafią lub wręcz nie chcą dostrzec. Jednocześnie budżet partycypacyjny w Polsce wciąż pozostaje stosunkowo nowym narzędziem współpracy między władzą lokalną, a obywatelami. Brak troski o jego prawidłowy rozwój może spowodować jednak, że jego popularność wśród społeczności miejskich nie zostanie ugruntowana, a on sam stanie się narzędziem o marginalnym znaczeniu. Ryzyko sprowadzenia budżetu partycypacyjnego do swoistej fasady społecznego uczestnictwa w zarządzaniu gminą, jest szczególnie wysokie w dużych miastach, gdzie skłonienie do uczestnictwa w nim większości mieszkańców jest sporym wyzwaniem. Artykuł obserwując społeczne uczestnictwo mieszkańców największych miast $\mathrm{w}$ Polsce $\mathrm{w}$ budżecie obywatelskim, próbuje potwierdzić hipotezę o wciąż istniejącym deficycie społecznego uczestnictwa w budżetowaniu partycypacyjnym na terenie dużych aglomeracji miejskich w Polsce, którego wyrazem pozostaje niska frekwencja, tak w procesie zgłaszania propozycji projektów, jak i późniejszego głosowania nad nimi. Zakres czasowy analizy obejmuje lata 2015-2018. Praca wskazuje również przyczyny rosnącej popularności budżetu partycypacyjnego jako narzędzia zarządzania wśród władz gmin i miast, a takżena korzyści i zagrożenia płynące ze stoso-

1 Mgr Paweł Ostachowski, Instytut Nauk o Polityce i Administracji, Uniwersytet Pedagogiczny im. Komisji Edukacji Narodowej w Krakowie. 
wania tej formy współpracy władz lokalnych z mieszkańcami. Fundament metodologiczny pracy stanowi w tym przypadku, tak analiza współcześnie wykorzystywanych podstaw budżetowania partycypacyjnego w Polsce, jak i niedawno powstałych raportów organizacji pozarządowych skupiających uwagę na tej właśnie problematyce.

\section{Początki, zasady i motywy budżetowania partycypacyjnego w Polsce}

Spoglądając na polski samorząd terytorialny po 1989 r., próżno szukać w momencie jego przywrócenia szeroko rozwiniętej partycypacji obywatelskiej, czy gwarantowanych ustawą rozwiniętych form współuczestnictwa społeczności lokalnych w wydatkach miejskich. Szybko rosnąca jeszcze w latach 80tych dwudziestego wieku sieć organizacji lokalnych oraz stowarzyszeń realizujących zadania $\mathrm{z}$ zakresu bezpieczeństwa lokalnego, $\mathrm{z}$ rezerwą odnosiła się do współpracy z kruszącą się już władzą partyjną. Wzajemna, wytworzona wówczas nieufność, dopiero w latach 90tych, a więc w momencie transformacji z socjalistycznej dyktatury do demokracji, miała szansę na przezwyciężenie ${ }^{2}$. Niepewna sytuacja gospodarcza, rosnące bieda i bezrobocie, problemy przekształceń własnościowych, wreszcie skromne zasoby finansowe samorządów lokalnych spowodowały, że budżet partycypacyjny nie miał szansy zaistnienia. Władze lokalne skierowały uwagę w kierunku najważniejszych problemów, pozostawiając mieszkańcom minimalną przestrzeń do decydowania o kwestiach finansowych.

Także ustawodawstwo, mimo istnienia obligatoryjnych narzędzi partycypacji społecznej, przyjmujących formę konsultacji społecznych, długo unikało formuły bezpośredniego oddawania prawa do decydowania o finansach lokalnych w ręce obywateli. Przyjęta wówczas w Polsce formuła konsultacji społecznych, o której mówi obecnie art. 5a ustawy o samorządzie gminnym (u.s.g) ${ }^{3}$, nierzadko do dziś pozostaje okryta złą sławą jako narzędzie służące, co prawda do wysłuchania mieszkańców, lecz o znikomym wpływie na ostateczny kształt decyzji władz lokalnych. Niedawno w samym artykule umiejscowiono jednak też najważniejsze przepisy dotyczące budżetu obywatelskiego. Precyzuje on, że jest to szczególna forma konsultacji społecznych, w których mieszkańcy w bezpośrednim głosowaniu decydują corocznie o części wydatków budżetu gminy. Wskazuje również, że zadania wybrane w ramach budżetu obywatelskiego zostają uwzględnione w uchwale budżetowej tej jednostki samorządowej ${ }^{4}$. Jednocześnie ustawodawca wprowadził zabezpieczenie przed

2 J. Podgórska-Rykała, Budżet obywatelski jako przykład współdecydowania o rozwoju na szczeblu samorzadowym wobec zmian prawnych z 2018 roku, „Zeszyty Naukowe Wyższej Szkoły Humanitas. Zarządzanie”, nr 1/2018, s. 79.

3 Dz. U. z 2020 r. poz. 713.

4 Ibidem, art 5a, pkt. 3 i 4. 
pokusą istotnej ingerencji organu stanowiącego w zadania wybrane przez mieszkańców w ramach budżetu obywatelskiego. Rada gminy nie może, bowiem ich usuwać lub zmieniać wedle własnego uznania, a zatem jest związana decyzjami mieszkańców, co do ich wyboru. Jednocześnie organ stanowiący gminy, w drodze uchwały podejmuje kluczowe decyzje dotyczące standardów, jakie spełniać musi budżet obywatelski. Chodzi tu w pierwszej kolejności o wymogi formalne, którym powinny czynić zadość projekty w nim zgłaszane. Rada gminy ustala również poziom minimalnego ich poparcia przez mieszkańców, warunkujący kwalifikację do głosowania. Decyduje też o zasadach oceny zgłoszonych projektów, ich zgodności z prawem, technicznych możliwościach wykonania, czy trybie, w którym przedstawiający projekt mogą odwołać się od decyzji o jego odrzuceniu z głosowania ${ }^{5}$. Ustawą z 11 stycznia 2018 r. o zmianie niektórych ustaw $w$ celu zwiększenia udziału obywateli $w$ procesie wybierania, funkcjonowania $i$ kontrolowania niektórych organów publicznych uzupełniła przepisy o nowe regulacje, wprowadzające możliwość realizacji budżetów obywatelskich także przez powiaty i województwa ${ }^{6}$. Te pierwsze obowiązkowo muszą mieć budżety obywatelskie, których wysokość nie może być niższa niż $0,5 \%$ wydatków gminy zawartych $\mathrm{w}$ ostatnim przedłożonym sprawozdaniu $\mathrm{z}$ wykonania budżetu. Jednocześnie środki budżetu partycypacyjnego mogą być dzielone na części odpowiadające jednostkom pomocniczym, które funkcjonują w ramach funkcjonowania samorządów (dzielnice, osiedla) ${ }^{7}$. Warto jednocześnie pamiętać, że budżet partycypacyjny będąc na mocy art. 5a ust.4 u.s.g od końca 2018 r., nie podlega już tylko nadzorowi ogólnemu, sprawowanemu przez wojewodów, ale jako część budżetu lokalnego kontrolowany jest, co do swej prawidłowości przez właściwą miejscowo regionalną izbę obrachunkową.

Wydaje się, że społeczeństwo polskie lat 90tych dwudziestego wieku nie było w pełni gotowe na rozwiązanie takie jak budżet partycypacyjny, gdzie miałoby ono podjąć współpracę z władzą lokalną, której autorytet wciąż nie był najwyższy. Trzeba było kilkunastu lat, aby idea budżetu obywatelskiego trafiła na grunt polski. Jako pierwsze miasto w Polsce budżet partycypacyjny w $2011 \mathrm{r}$. wprowadził Sopot ${ }^{9}$. Dwa lata później różne jego formy przy planowaniu wydatków posiadały już m.in. Bydgoszcz, Cho-

5 Nie może być ona większa niż 0,1\% mieszkańców terenu objętego pulą budżetu obywatelskiego, w którym zgłaszany jest projekt; art. 5a pkt 7 ustawy 8 marca 1990 r., o samorzadzie gminnym, Dz. U. z 2020 r. poz. 713.

6 Budżety obywatelskie w gminach na nowych zasadach, https://www.rp.pl/Finanse/ 303129985-Budzety-obywatelskie-w-gminach-na-nowych-zasadach.html, (1.09.2020).

7 art. 5a pkt 6ustawy 8 marca 1990 r., o samorzadzie gminnym, Dz. U. z 2020 r. poz. $713,1378$.

8 Budżety obywatelskie w gminach..., (1.09.2020).

9 D. Krzysztofowicz, Mieszkańcy chca sami decydować o wydatkach, „Wspólnota”, Nr 13/1123, s. 8. 
rzów, Elbląg, Płock, Poznań, Tarnów, Toruń, Wałbrzych, Włocławek, Wrocław i Zielona Góra ${ }^{10}$.

Wielu badaczy tej problematyki sięga do doświadczeń wypracowanych w Płocku w latach 2003-2005. Tam to władze miejskie przy wsparciu lokalnego potentata branży petrochemicznej PKN Orlen i Organizacji Narodów Zjednoczonych powołały innowacyjny wówczas w skali kraju fundusz grantowy skierowany do lokalnych organizacji pozarządowych, które mogły otrzymać środki w nim zgromadzone po przedstawieniu konkretnych projektów skierowanych ku otoczeniu lokalnemu ${ }^{11}$. Choć środki funduszu nie pochodziły jeszcze z budżetu miasta, można uznać tę inicjatywę za bliską budżetowaniu partycypacyjnemu.

Być może długi okres oczekiwania na pojawienie się budżetu partycypacyjnego w polskich miastach należy tłumaczyć też brakiem otwartości władz do jego tworzenia. Długo trwał także proces finansowego stabilizowania się polskiego samorządu terytorialnego. Dopiero ustawa o dochodach jednostek samorządu terytorialnego z 2003 r., stworzyła trwały fundament postępującej emancypacji finansowej samorządów lokalnych ${ }^{12}$. Przyśpieszyły ją również płynące do miast środki z funduszy europejskich. Nadrabianie luki infrastrukturalnej w polskich miastach i poza nimi, jak i nieznajomość narzędzi partycypacyjnych wśród polskich liderów lokalnych sprawiły, że pojawiły się one stosunkowo późno, spotykając się jednocześnie z dużą rezerwą ze strony społeczności lokalnych. Mimo tego, po 2013 r. budżet partycypacyjny stał się jedną z popularniejszych inicjatyw skierowanych do mieszkańców miast $\mathrm{w}$ celu zachęcenia ich do współuczestnictwa w zarządzaniu przestrzenią miejską ${ }^{13}$.

Tymczasem, forma partycypacji społeczeństwa w procesie zarządzania miastem, jaką jest budżet partycypacyjny przyjęła się dobrze w wielu krajach świata ${ }^{14}$. Jego specyfika pozwala na dopasowywanie go do przyjętych celów i warunków. Co więcej, w Polsce ma on również swój odpowiednik na obszarach wiejskich, gdzie jego funkcje realizuje fundusz sołecki, działający w oparciu o ustawę o funduszu sołeckim z 2014 r. ${ }^{15}$. Kolebka budżetu partycypacyjnego to jednak Ameryka Południowa, gdzie po raz pierwszy w Porto Alegre, stolicy stanu Rio Grande do Sul w Brazylii, zastosowano

10 A. Żabka, H. Łapińska, Budżet partycypacyjny, a rozwój lokalny, „Zeszyty Naukowe Wyższej Szkoły Finansów i Prawa", nr 4/2014, s. 67.

11 W. Kębłowski, Budżet partycypacyjny - krótka instrukcja obsługi, Warszawa 2013, s. 16.

12 Dz.U. z 2020 r., poz. 23.

13 B. Sorychta-Wojsczyk, Uwarunkowania wykorzystania budżetu obywatelskiego $w$ administracji publicznej w Polsce, „Zeszyty Naukowe Politechniki Śląskiej, Seria: Organizacja i zarządzanie", 2015, s. 78.

14 M. Wiśniewska, Budżet obywatelski w polskich miastach - doświadczenia w województwie łódzkim, „Studia Miejskie”, 2018, nr 29, s. 36.

15 M. Wójcik, Fundusz sołecki w świetle nowych regulacji prawnych, „Prawo budżetowe Państwa i Samorządu, 2014, nr 2(4), s. 47. 
go w końcu lat 80tych dwudziestego wieku. Jego powstanie poprzedziła tam działalność licznych ruchów społecznych, prowadzących wspólną działalność jako Związek Stowarzyszeń Sąsiedzkich Porto Alegre. To one stworzyły tam skuteczne strategie współpracy z mieszkańcami oraz wypracowały efektywne narzędzia partycypacyjne ${ }^{16}$. Widać tutaj zasadniczą różnicę w funkcji, jaką spełnia on w Polsce. Budżet partycypacyjny w Porto Alegre miał za zadanie przeprowadzenie oddolnej reformy społecznej, a wzmacnianie demokracji i wspieranie partycypacji nie były jego celem, lecz sposobem prowadzącym do zmiany społecznej ${ }^{17}$. Tymczasem w Polsce nie jest on zazwyczaj efektem oddolnie kierowanej inicjatywy obywatelskiej, a tej pochodzącej od władz lokalnych. Jednocześnie bliżej mu do narzędzia, którego celem jest głównie wspieranie partycypacji, mniej zaś do tego stanowiącego istotne narzędzie redystrybucji miejskich dochodów. Wystarczy dodać tylko, że w 2004 r., mieszkańcy angażujący się w budżet partycypacyjny Porto Alegre mieli do dyspozycji 1/5 wszystkich funduszy tego miasta, podczas gdy nawet dziś w polskich dużych miastach poziom ten jest o wiele niższy ${ }^{18}$.

Do 2008 r. budżet partycypacyjny pojawił się w blisko 200 miastach Brazylii - swoim oddziaływaniem obejmując ok. $44 \mathrm{mln}$ obywateli. Dwa lata później realizowało go już ok. 510 miast Ameryki Południowej ${ }^{19}$. Szybko zyskał charakter ogólnoświatowy upowszechniając się w Europie, Afryce, Azji i Ameryce Północnej ${ }^{20}$. Na koniec 2013 r. realizowało go już blisko 800 miast. Pokazuje szybko rosnące zainteresowanie tą formą współdecydowania społeczności lokalnych o zarządzaniu przestrzenią miejskąą ${ }^{21}$ Równieżw polskich miastach budżet partycypacyjny do dziś cechuje ekspansja. $\mathrm{Na}$ koniec 2015 r., realizowało go już 80 polskich samorządów ${ }^{22}$. Doskonałym przykładem jest tu region łódzki, gdzie do końca 2016 r., budżet partycypacyjny wdrożyło 16 miast. Trzy z nich to małe ośrodki, zamieszkałe przez mniej niż 20 tys. osób. Trzy kolejne to miasta liczące do 40 tysięcy mieszkańców. Kolejne dziewięć to ośrodki zamieszkałe przez mniej niż 100 tysię-

16 B. Pytlik, Budżet partycypacyjny w Polsce. Ewolucja i dylematy, „Studia z Polityki Publicznej", 2017, nr 1(13), s. 106.

17 P. Sadura, Podzielmy się kulturą. Budżet partycypacyjny w Domu Kultury Śródmieście. Opis procesu wraz z rekomendacjami, Warszawa 2013, s. 11.

18 B. Pytlik, Budżet partycypacyjny..., s. 107.

19 M. Wiśniewska, Budżet obywatelski..., s. 38.

20 Ganuza E., Baiocchi G., The power of ambiguity: How participatory budgeting travels the globe, $\mathrm{w}$ : The spread of participatory budgeting across the globe: Adoption, adaptation, and impacts, „Journal of Public Deliberation”, vol. 8, 2012, No 2, s. 66.

21 W. Kębłowski, Budżet partycypacyjny..., s. 18.

22 M. Kołodziej-Hajdo, Budżet partycypacyjny, jako instrument zarzadzania publicznego w koncepcji public governance na przykładzie miasta Krakowa, „Studia Ekonomiczne. Zeszyty Naukowe Uniwersytetu Ekonomicznego w Katowicach", 2017, nr 341, s. 74 . 
cy mieszkańców. Budżet partycypacyjny wdrożyła również będąca stolicą regionu Łódź23.

Poszukując przyczyn, dla których władze lokalne w Polsce podejmują decyzję o wdrożeniu budżetu partycypacyjnego w lokalny model zarządzania można wskazać rozmaite motywacje. Jedną z ważniejszych jest ekspansja tego rozwiązania w skali międzynarodowej i towarzyszące mu pozytywne opinie ekspertów, co do jego skuteczności. Mimo wielu lat funkcjonowania budżetu partycypacyjnego na świecie, wciąż jest on dla wielu społeczności lokalnych w Polsce rozwiązaniem innowacyjnym. Te zaś, zarówno z punktu widzenia władz lokalnych jak i mieszkańców zwykle cieszą się zainteresowaniem. Problem pojawia się, gdy początkowo interesujące rozwiązanie, z czasem okazuje się nie spełniać pokładanych w nim oczekiwań. Wówczas zainteresowanie nim spada, nie mówiąc już o przyciągnięciu do niego nowych grup potencjalnych uczestników, jak choćby ludzi młodych.

Lokalni politycy stają się coraz bardziej świadomi tego, że nawet skuteczne rządy w sytuacji braku rosnącej partycypacji społecznej, mogą być niewystarczające do wygrania kolejnych wyborów. Włączenie mieszkańców w proces decyzyjny przez budżet partycypacyjny umacnia więc ich wizerunek jako przyjaznych mieszkańcom. Częściowo przenosi jednocześnie odpowiedzialność za otoczenie w ich ręce. Wydaje się to korzystne zwłaszcza na obszarze dużych miast, gdzie liczba mikro problemów wymagających podjęcia działań jest zbyt duża w stosunku do możliwości ich ewidencji i rozwiązywania przez miejską administrację. Tymczasem mieszkańcy o wiele szybciej i skuteczniej identyfikują potrzeby swojego otoczenia. Za pomocą budżetu partycypacyjnego mogą je natomiast zaspokoić. Nawet nowoczesna architektura miejska, nowa droga, czy chodnik mogą bowiem nie spełniać swej funkcji i wręcz pogarszać jakość życia mieszkańców, jeśli powstały w oderwaniu od ich faktycznych potrzeb i interesów.

\section{Zagrożenia dla budżetu partycypacyjnego}

Nie ulega wątpliwości, że jest on narzędziem przynoszącym korzyści wielu podmiotom. Mieszkańcy zyskują możliwość częściowego wpływu na najbliższą im przestrzeń miasta. Władze mogą rozszerzyć spektrum swojego spojrzenia na jego rozwój, bez konieczności rozbudowy administracji. Zyskują też organizacje pozarządowe, dla których budżet partycypacyjny przy współpracy z mieszkańcami stać się może narzędziem realizacji ich celów statutowych - na przykład tych dotyczących ochrony przyrody, gospodarki odpadami,czy ochrony zwierząt. Sektor usług komercyjnych przez budżet partycypacyjny także zyskuje. Poprawiają się warunki prowadzenia działalności gospodarczej. Powstaje też nowy obszar realizacji zysków w ramach

23 M. Wiśniewska, Budżet obywatelski..., s. 40. 
partnerstwa publiczno-prywatnego. Dochodzi też do zmiany alokacji funduszy miast sprzyjającej poprawie warunków życia w ich najbiedniejszych ${ }^{24}$.

Mimo wielu korzyści z wdrażania budżetów partycypacyjnych na świecie i w Polsce, nie brakuje też barier i wyzwań stojących przed ich twórcami i realizatorami. Najtrudniejsze pozostaje zapewnienie rosnącego udziału społeczności lokalnych $\mathrm{w}$ jego tworzeniu ${ }^{25}$. Utrzymanie zainteresowania mieszkańców budżetem partycypacyjnym jest trudne. Widać to podczas głosowań projektów do realizacji w dużych polskich miastach, w których uczestniczy mniej niż połowa mieszkańców. Niejednokrotnie sam dobór formy, za pomocą której oddawany jest głos, może wręcz utrudniać lub wykluczać przynajmniej część mieszkańców. Przykładem może być tu choćby przyjęcie wyłącznie elektronicznej metody głosowania, de facto dyskryminującej osoby objęte wykluczeniem cyfrowym.

Także politycy lokalni mogą stać się zagrożeniem dla idei budżetu partycypacyjnego. Jest tak m.in. w sytuacji, gdy nie wykazują oni większego zaangażowania w projekt lub obawiają się utraty wpływu na kształt budżetu miasta wskutek wzmocnienia partycypacyjnych mechanizmów zarządzania. Ich instrumentalne podejście do budżetowania partycypacyjnego, wydaje się częste w czasie kampanii samorządowej, kiedy to wykazują szczególnie silną aktywność ustanawiania jak i modyfikacji działania budżetów partycypacyjnych. Hasła takie trafiają wówczas do programów wyborczych kandydatów, jak i przyjmują formę gotowych rozwiązań legislacyjnych. Zagrożeniem dla rozwoju budżetów partycypacyjnych mogą stać się wreszcie zbyt wygórowane oczekiwania mieszkańców wobec tej formy podziału funduszy miejskich. Chodzi przede wszystkim o sytuację, w której projekty wybrane do realizacji okazują się nie mieścić w jego finansowych ramach wyznaczonych przez władze miejskie.

\section{Praktyka budżetu partycypacyjnego w wielkich miastach Polski}

Budżety partycypacyjne w większych polskich miastach działają od co najmniej 2012 r., pozwala to już na ocenę ich skuteczności oraz odniesienie się do negatywnych zjawisk, które im towarzyszą. Uwaga artykułu skupia się w tym wypadku na Warszawie, Krakowie, Łodzi, Wrocławiu, Poznaniu i Gdańsku w latach 2014-2018. Zjawiskiem dostrzegalnym w każdym z tych miast był spadek zainteresowania mieszkańców budżetem partycypacyjnym. Jeszcze w $2014 \mathrm{r}$. w sześciu analizowanych miastach udział w nim brało w sumie 654196 mieszkańców. Rok później było ich o 19889 mniej ${ }^{26}$. Aktywność tą w poszczególnych miastach dokładniej pokazuje wykres.

24 B. Sorychta-Wojsczyk, Uwarunkowania wykorzystania..., s. 82.

25 Ibidem, s. 84.

26 Raport: budżet obywatelski w polskich miastach, Warszawa 2019, s. 4. 
Wykres 1. Głosujący na projekty w budżetach obywatelskich, w największych miastach Polski w latach 2014-2018.

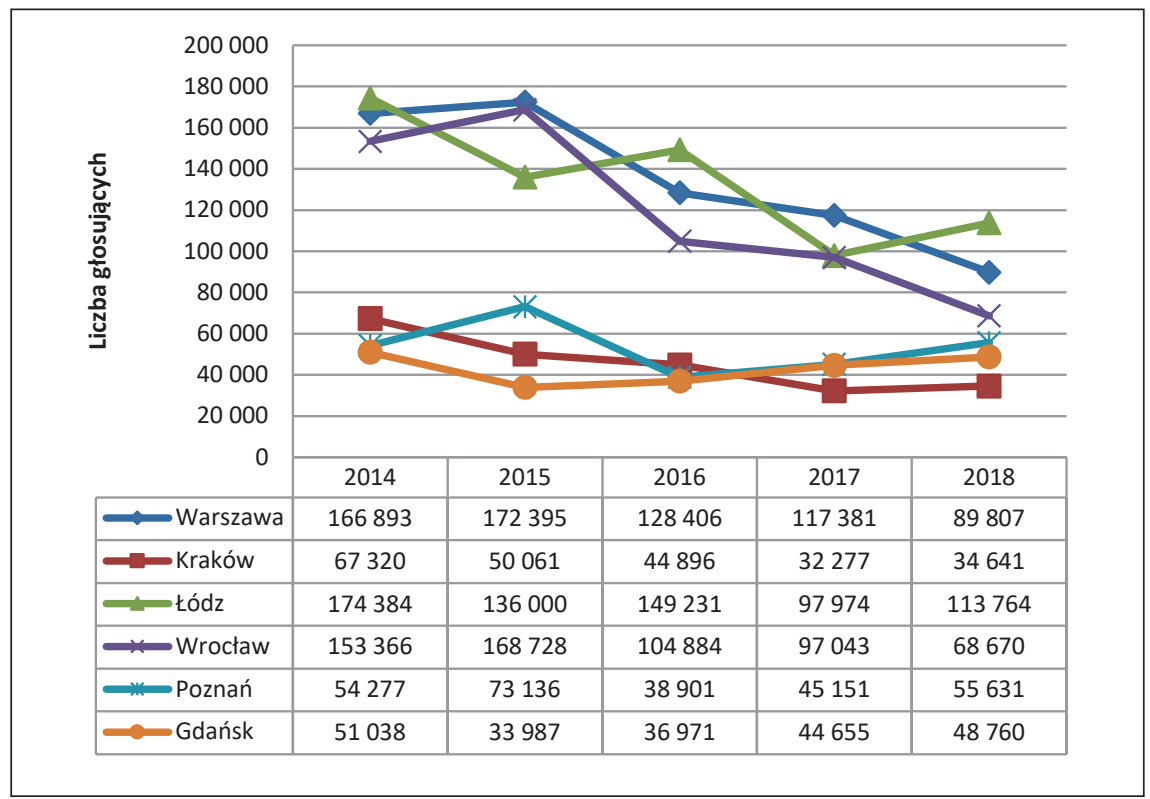

Źródło: opracowanie własne na podstawie; https://www.gdansk.pl/budzet-obywatelski; https://uml.lodz.pl/budzet-obywatelski: https://twojbudzet.um.warszawa.pl//https://budzet. um.poznan.pl/pbo; https://budzet.krakow.pl; https://www.wroclaw.pl/rozmawia/wroclawski-budzet-obywatelski (12.09.2020).

Dane z wykresu 1 informują, że w 2016 r., zainteresowanych projektami w ramach budżetów partycypacyjnych tych miast było już o blisko 151 tys. osób mniej niż dwa lata wcześniej. W 2018 r. aktywny udział w wyborze projektów budżetu partycypacyjnego dotyczył 411273 mieszkańców badanych miast, czyli ponad 37\% mniej niż w $2014 \mathrm{r}^{27}$. Wydaje się to niewiele w porównaniu do liczby zamieszkujących te miasta. Potwierdza to także frekwencja $\mathrm{w}$ głosowaniach nad projektami zgłoszonymi do poszczególnych edycji budżetów partycypacyjnych, prezentowana na wykresie 1 dla poszczególnych miast. Dla przykładu w samym tylko 2018 r., najwięcej bo $16,4 \%$ uprawnionych do głosowania mieszkańców zagłosowało za projektami budżetu obywatelskiego w Łodzi. Jeszcze słabiej wypadła ona we Wrocławiu (10,76\%), Gdańsku (10,50\%), Poznaniu (10,31\%) i Warszawie (5,11\%). Najsłabszy wynik w 2018 r. odnotowano w Krakowie, na poziomie tylko $4,52 \%{ }^{28}$. Bliższe spojrzenie na budżety obywatelskie poszczególnych miast pokazuje jeszcze dokładniej ich siłę przyciągania społecznego i możliwości, jakie przekazały im władze miejskie.

Warszawa nie tylko jako stolica kraju, ale i największy ośrodek wzrostu gospodarczego oraz nowych technologii w kraju, od lat dysponuje najwyż-

27 Ibidem, s. 4.

28 Ibidem, s. 7. 
szym budżetem lokalnym. Jednocześnie jej rozległość terytorialna i zróżnicowanie poziomu życia mieszkańców poszczególnych dzielnic, winny skłaniać jej władze do rozwijania budżetu partycypacyjnego. Po jego dobrym debiucie w 2014 r., kiedy udział w nim zadeklarowało 166893 osób, w 2015 r., odnotowano wzrost zainteresowania. Decyzja z 2016 r., wykluczająca możliwość oddawania głosów na projekty w formie papierowej odwróciła jednak ów trend. W 2018 r.,w blisko dwumilionowej Warszawie budżet obywatelski zainteresował tylko 89807 mieszkańców, czyli o 46,18\% osób mniej niż w 2014 r. Kwota przeznaczona na realizację zadań w ramach budżetu obywatelskiego stolicy w latach 2015-2018 r., wzrosła jednak z 26,2 do ponad $61 \mathrm{mln}$ zł. Taki poziom finansowania budżetu partycypacyjnego był najwyższy w kraju lecz blednie przy możliwościach finansowych, jak i skali potrzeb tego rosnącego w błyskawicznym tempie wielkiego miasta ${ }^{29}$. Warszawa była też miastem, gdzie corocznie proponowano, jak i wybierano do realizacji najwięcej zadań w kraju. W latach 2015-2018 było ich w sumie 2631. Szczegóły prezentuje tabela 1.

Tabela 1. Proponowane i zrealizowane zadania budżetu partycypacyjnego Warszawy w latach 2015-2018.

\begin{tabular}{|l|c|c|c|c|}
\hline \multicolumn{1}{|c|}{ Rok } & $\mathbf{2 0 1 5}$ & $\mathbf{2 0 1 6}$ & $\mathbf{2 0 1 7}$ & $\mathbf{2 0 1 8}$ \\
\hline Liczba zgłoszonych projektów & 2234 & 2333 & 2649 & 2782 \\
\hline Liczba zrealizowanych projektów & 336 & 644 & 770 & 881 \\
\hline
\end{tabular}

Źródło: opracowanie własne na podstawie: https://twojbudzet.um.warszawa.pl, (12.09.2020).

Drugim co do wielkości miastem w Polsce pozostaje Kraków. Budżet partycypacyjny cieszył się w nim najmniejszym zainteresowaniem, w 2017 r. na projekty głos oddało 32277 mieszkańców, wobec 67320 osób trzy lata wcześniej. Rok później władzom udało się nieco odbudować to zainteresowanie. Nie zarzucono też tradycyjnej formy głosowania na papierze. Liczba proponowanych przez mieszkańców do realizacji zadańw latach 2014-2018 wahała się natomiast od 587 do $678^{30}$. Finansowanie krakowskiego budżetu partycypacyjnego w 2014 r., wyniosło $4,5 \mathrm{mln}$ zł. Na głowę mieszkańca przeznaczono zatem kwotę niecałych $6 \mathrm{zł}$. W tym samym roku na mieszkańca Łodzi wyniosła ona ponad 57 zł. We Wrocławiu było to 32 zł, a w Gdańsku i w Poznaniu odpowiednio $24 \mathrm{zł} \mathrm{i} 18 \mathrm{zt}^{31}$. Wsparcie finansowe kolejnych edycji przedstawiało się już o wiele lepiej. W 2015 r. wyniosło ono już ponad $10 \mathrm{mln} \mathrm{z} \mathrm{z}^{32}$, a rok później sięgnęło 10,9 mln zł. Zmiany wprowadzone do

29 Raport: budżet obywatelski..., s. 11.

30 Raport ewaluacyjny VI edycji Budżetu Obywatelskiego Miasta Krakowa, Kraków 2019, s. 5.

31 Ewaluacja pierwszej edycji Budżetu Obywatelskiego w Krakowie, Warszawa-Kraków 2014, s. 13.

32 Ewaluacja drugiej edycji Budżetu Obywatelskiego w Krakowie, Warszawa-Kraków 2015, s. 9. 
ustawy o samorządzie gminnym w 2018 r. spowodowały podniesienie kwoty na edycję budżetu partycypacyjnego Krakowa na rok 2019, do kwoty 30 mln zł, a więc do wymaganego przepisami 0,5\% wydatków tego miasta. Stał się on wówczas czwartym pod względem wysokości przekazanych środków budżetem obywatelskim w kraju, zaraz po Warszawie, Łodzi i Katowicach ${ }^{33}$. Mimo to, zazwyczaj do realizacji trafiała mniej niż $1 / 5$ proponowanych przez mieszkańców projektów, co prezentuje tabela 2.

Tabela 2. Proponowane i zrealizowane zadania budżetu partycypacyjnego Krakowa w latach 2015-2018.

\begin{tabular}{|l|c|c|c|c|}
\hline \multicolumn{1}{|c|}{ Rok } & 2015 & 2016 & 2017 & 2018 \\
\hline Liczba zgłoszonych projektów & 627 & 611 & 578 & 678 \\
\hline Liczba zrealizowanych projektów & 111 & 90 & 93 & 114 \\
\hline
\end{tabular}

Źródło: opracowanie własne na podstawie: Raport ewaluacyjny V edycja Budżetu Obywatelskiego, Kraków 2018, s. 7.

Mimo wciąż utrzymującej się powolnej depopulacji Łodzi, pozostaje ona trzecim co do wielkości miastem w Polsce. Również tutaj 2017 rok przyniósł kryzys frekwencji w budżecie partycypacyjnym, kiedy zainteresowanie jego zadaniami wyraziło w głosowaniu 97974 mieszkańców. Było to jednak o 65697 osób więcej niż w Krakowie w tym samym roku. Od 2015 r. Łódź przeznaczała największe środki po Warszawie na finansowanie swoich zadań z budżetu obywatelskiego. W połączeniu z mniejszą niż w Warszawie liczbą mieszkańców sprawia to, że finansowanie budżetu partycypacyjnego Łodzi na głowę mieszkańca jest do dziś największe w Polsce. W latach 2015-2018 pojawiało się jednocześnie więcej propozycji projektów niż w Krakowie, z których znaczna ilość trafiała do realizacji. Informuje o tym tabela 3.

Tabela 3. Proponowane i zrealizowane zadania budżetu partycypacyjnego Łodzi w latach 2015-2018.

\begin{tabular}{|l|c|c|c|c|}
\hline \multicolumn{1}{|c|}{ Rok } & 2015 & 2016 & 2017 & 2018 \\
\hline Liczba zgłoszonych projektów & 871 & 650 & 1572 & 1131 \\
\hline Liczba zrealizowanych projektów & 65 & 87 & 218 & 234 \\
\hline
\end{tabular}

Źródło: opracowanie własne na podstawie: https://uml.lodz.pl/budzet-obywatelski/edycje-minione, (12.09.2020).

Być może dlatego zainteresowanie budżetem partycypacyjnym ze strony mieszkańców Łodzi okazuje się większe niż w Krakowie, udaje się bowiem realizować większą liczbę projektów, zwłaszcza po $2017 \mathrm{r}^{34}$.

33 Raport ewaluacyjny - VI edycji..., s. 7.

34 Raport: budżet obywatelski..., s. 18. 
Wrocław to największe miasto na Dolnym Śląsku, gdzie zainteresowanie mieszkańców budżetem obywatelskim w 2015 r. dorównywało temu w stolicy Polski. Wrocław osiągnął wówczas własny rekord frekwencji udziału mieszkańców w głosowaniu nad projektami w budżecie partycypacyjnym. Aż 26,3\% mieszkańców miasta uczestniczyło wówczas w jego tworzeniu, zgłaszając do realizacji zadania oraz głosując. Kolejne lata zmniejszyłyto zainteresowanie. Budżet partycypacyjny miasta w 2018 r. przyciągnął uwagę już o 59,3\% mniej mieszkańców niż trzy lata wcześniej. Spadek jego popularności był szczególnie dotkliwy wśród młodych ludzi w wieku 16-30 lat ${ }^{35}$. Pojawiało się coraz mniej zgłoszeń projektów. Nie wzrastała też liczba zadań przyjętych do realizacji, co pokazuje tabela 4 .

Tabela 4. Proponowane i zrealizowane zadania budżetu partycypacyjnego Wrocławia w latach 2015-2018.

\begin{tabular}{|l|c|c|c|c|}
\hline \multicolumn{1}{|c|}{ Rok } & $\mathbf{2 0 1 5}$ & $\mathbf{2 0 1 6}$ & $\mathbf{2 0 1 7}$ & $\mathbf{2 0 1 8}$ \\
\hline Liczba zgłoszonych projektów & 810 & 788 & 749 & 645 \\
\hline Liczba zrealizowanych projektów & 80 & 65 & 64 & 63 \\
\hline
\end{tabular}

Źródło: opracowanie własne na podstawie: https://www.wroclaw.pl/rozmawia/wroclawski-budzet-obywatelski, (12.09.2020).

Poznań to miasto z najdłuższą tradycją funkcjonowania budżetu partycypacyjnego. Pojawił się on tam w 2012 r. Rok później zainteresowanie tym narzędziem okazało się największe $\mathrm{w}$ historii jego funkcjonowania w tym mieście. Kryzys popularności budżetu partycypacyjnego miał tu miejsce w 2016 r., kiedy zwróciło na niego uwagę jedynie 38901 mieszkańców, wobec 73136 rok wcześniej. Budżet partycypacyjny Poznania cechuje mniejsza liczba zgłaszanych zadań niż w Warszawie, czy Łodzi, co prezentuje tabela 5 .

Tabela 5. Proponowane i zrealizowane zadania budżetu partycypacyjnego Poznania w latach 2015-2018.

\begin{tabular}{|l|c|c|c|c|}
\hline \multicolumn{1}{|c|}{ Rok } & $\mathbf{2 0 1 5}$ & $\mathbf{2 0 1 6}$ & $\mathbf{2 0 1 7}$ & $\mathbf{2 0 1 8}$ \\
\hline Liczba zgłoszonych projektów & 207 & 272 & 234 & 327 \\
\hline Liczba zrealizowanych projektów & 20 & 38 & 47 & 34 \\
\hline
\end{tabular}

Źródło: opracowanie własne na podstawie: https://budzet.um.poznan.pl/pbo21/poprzednie-edycje-pbo, (12.09.2020).

Połączenie tej sytuacji ze spadkiem liczby projektów do realizacji w latach 2016-2017 spowodowało, że wartości poszczególnych zadań w ramach budżetu obywatelskiego Poznania są znacznie wyższe niż w innych miastach. Finansowanie budżetu partycypacyjnego tego miasta $\mathrm{w}$ latach

35 Ibidem, s. 19. 
2014-2018, wahało się w przedziale 15-20 mln zł, co było wielkością porównywalną do tej w Gdańsku ${ }^{36}$.

Ta nazywana kolebką „Solidarności”, stolica województwa pomorskiego, to miasto, w którym budżet partycypacyjny w latach 2014-2018 notował najmniejsze wahania frekwencji. Największe zainteresowanie gdańszczan tym narzędziem wystąpiło w 2014 r., kiedy na propozycje projektów zagłosowało 51038 osób. Dwa lata później było to już jedynie 33897 mieszkańców, za co głównie winić należy niewystarczającą kampanię informacyjną władz miasta. Finansowanie budżetu partycypacyjnego w Gdańsku w latach 2015-2018 wahało się w przedziale od 11 do $20 \mathrm{mln}$ zł. ${ }^{37}$. Zwiększyła się też liczba projektów miejskich poddawanych pod głosowanie, jak i tych kierowanych do realizacji. Informuje o tym tabela 6 .

Tabela 6. Proponowane i zrealizowane zadania budżetu partycypacyjnego Gdańska w latach 2015-2018.

\begin{tabular}{|l|c|c|c|c|}
\hline \multicolumn{1}{|c|}{ Rok } & $\mathbf{2 0 1 5}$ & $\mathbf{2 0 1 6}$ & $\mathbf{2 0 1 7}$ & $\mathbf{2 0 1 8}$ \\
\hline Liczba zgłoszonych projektów & 210 & 254 & 297 & 319 \\
\hline Liczba zrealizowanych projektów & 21 & 65 & 90 & 105 \\
\hline
\end{tabular}

Źródło: opracowanie własne na podstawie: https://budzet.um.poznan.pl/pbo21/poprzednie-edycje-pbo, (12.09.2020).

Gdańsk wydaje się być zatem jedynym dużym miastem, które w ostatnich latach utrzymuje stabilizację budżetu partycypacyjnego, tak pod względem frekwencyjnym, jak i $\mathrm{w}$ aspekcie wzrostu inicjatyw projektowych wśród mieszkańców.

\section{Wnioski}

Budżet partycypacyjny jest narzędziem coraz częściej obecnym w zarządzaniu przestrzenią miejską. Przynosi konkretne korzyści społecznościom miejskim. Pozwala na zwiększenie wiedzy mieszkańców o funkcjonowaniu lokalnych finansów. Podnosi też poziom zaufaniado lokalnych polityków. Jednak jego rosnąca popularność w kolejnych miastach może okazać się zagrożona, zwłaszcza utrzymującym się brakiem szerszego nim zainteresowania ze strony mieszkańców.

Ustanowienie budżetu partycypacyjnego przez władze samorządowe bez tworzenia dla niego odpowiednich mechanizmów informacyjnych, skierowanych do mieszkańców wydaje się być niewystarczające. Stworzone wówczas narzędzie służy bowiem jedynie niewielkiemu odsetkowi tych, dla których w swej istocie powinien być instrumentem wsparcia. Przykład funkcjonowania budżetów partycypacyjnych $\mathrm{w}$ największych miastach

36 Raport: budżet obywatelski..., s. 21.

37 Raport: budżet obywatelski..., s. 21. 
Polski pokazuje $\mathrm{w}$ tym wypadku, że samo ich stworzenie i podtrzymywanie w przestrzeni miejskiej nie wystarczy. Uczestniczy w nich bowiem niewielka część populacji. Szczególnie niebezpieczny wydaje się zwłaszcza spadek zainteresowania młodych ludzi tą formą partycypacji społecznej. Jest on tym bardziej groźny, że to właśnie młodzi ludzie będą w przyszłości tworzyć lokalną tkankę społeczną, budować klimat współpracy i kompromisu dla wspólnych spraw ich podwórka, osiedla, dzielnicy czy gminy. Władze samorządowe nie mogą pozostawać bezczynne wobec tej sytuacji. Nie mogą sprowadzać tego narzędzia do roli modnej innowacji społecznej, którą warto stworzyć i posiadać, lecz niekoniecznie o nią dbać.

Wciąż w Polsce nie wypracowano jednolitych zasad zgłaszania i realizacji projektów. Dopiero w 2018 r., pojawiły się regulacje prawne dotyczące minimalnego finansowania budżetów partycypacyjnych w relacji do wydatków gminnych. Pokazuje to, że obecna pozycja budżetu partycypacyjnego w dużych, jak i mniejszych miastach Polski nie jest jeszcze ugruntowana i wymagać będzie jeszcze pracy władz lokalnych, jak i organizacji społecznych, w celu stworzenia maksymalnie skutecznego zestawu metod, środków i narzędzi umożliwiających dotarcie z jego ideą do szerokiego kręgu mieszkańców miast.

\section{Bibliografia}

Budzety obywatelskie $w$ gminach na nowych zasadach, https://www.rp.pl/Finanse/303129985-Budzety-obywatelskie-w-gminach-na-nowych-zasadach.html, (1.09.2020).

Czarnecki K., Udział mieszkańców w ustalaniu wydatków budżetu gminy w ramach tzw. budżetu partycypacyjnego na przykładzie Torunia $w$ latach 2013-2014, „Prawo Budżetowe Państwa i Samorządu”, nr 1(2)/2014.

Ewaluacja drugiej edycji Budżetu Obywatelskiego w Krakowie, Warszawa-Kraków 2015.

Ewaluacja pierwszej edycji Budżetu Obywatelskiego w Krakowie, Warszawa-Kraków 2014.

Ganuza E., Baiocchi G., The power of ambiguity: How participatory budgeting travels the globe, $\mathrm{w}$ : The spread of participatory budgeting across the globe: Adoption, adaptation, and impacts, "Journal of Public Deliberation" vol. 8, 2012, No 2 .

https://budzet.krakow.pl

https://budzet.um.poznan.pl/pbo

https://twojbudzet.um.warszawa.pl

https://uml.lodz.pl/budzet-obywatelski

https://www.gdansk.pl/budzet-obywatelski

https://www.wroclaw.pl/rozmawia/wroclawski-budzet-obywatelski

Kębłowski W., Budżet partycypacyjny - krótka instrukcja obsługi, Warszawa 2013. 
Kębłowski W., Budżet partycypacyjny. Ewaluacja, Instytut Obywatelski, Warszawa 2014.

Kołodziej-Hajdo M., Budżet partycypacyjny jako instrument zarządzania publicznego $w$ koncepcji public governance na przykładzie miasta Krakowa, Studia Ekonomiczne. Zeszyty Naukowe Uniwersytetu Ekonomicznego w Katowicach, nr $341 / 2017$.

Krzysztofowicz D., Mieszkańcy chca sami decydować o wydatkach, „Wspólnota”, Nr 13/1123, 22 czerwca 2013.

Podgórska-Rykała J., Budżet obywatelski jako przykład współdecydowania o rozwoju na szczeblu samorządowym wobec zmian prawnych z 2018 roku, „Zeszyty Naukowe Wyższej Szkoły Humanitas. Zarządzanie”, nr 1/2018.

Poniatowicz M., Kontrowersje wokót idei budżetowania partycypacyjnego jako instrumentu finansów lokalnych, „Studia Ekonomiczne. Zeszyty Naukowe Uniwersytetu Ekonomicznego w Katowicach", nr 198/2014.

Pytlik B., Budżet partycypacyjny w Polsce. Ewolucja i dylematy, „Studia z Polityki Publicznej”, 2017, nr 1(13).

Raport ewaluacyjny VI edycji Budżetu Obywatelskiego Miasta Krakowa, Kraków 2019.

Raport: budżet obywatelski w polskich miastach, Warszawa 2019.

Sadura P., Podzielmy się kulturą. Budżet partycypacyjny w Domu Kultury Śródmieście. Opis procesu wraz z rekomendacjami, Warszawa 2013.

Sorychta-Wojsczyk B, Uwarunkowania wykorzystania budżetu obywatelskiego $w$ administracji publicznej w Polsce, „Zeszyty Naukowe Politechniki Śląskiej, Seria: Organizacja i zarządzanie”, 2015, z. 78.

Ustawa z 11 stycznia 2018 r. o zmianie niektórych ustaw w celu zwiększenia udziału obywateli w procesie wybierania, funkcjonowania i kontrolowania niektórych organów publicznych, Dz.U. z 2018 r. poz. 130.

Ustawa z 8 marca 1990 r., o samorządzie gminnym, Dz. U. z 2020 r. poz. 713.

Wiśniewska M., Budżet obywatelski w polskich miastach - doświadczenia $w$ województwie łódzkim, „Studia Miejskie” 29/2018.

Wójcik M., Fundusz sołecki w świetle nowych regulacji prawnych, „Prawo budżetowe Państwa i Samorządu, 4(2) /2014.

Żabka A., Łapińska H., Budżet partycypacyjny a rozwój lokalny, Zeszyty Naukowe Wyższej Szkoły Finansów i Prawa, nr 4/2014.

Abstrakt

Artykuł przedstawia problematykę budżetu partycypacyjnego jako szybko rozwijającego się współczesnego narzędzia partycypacji mieszkańców miast w zarządzaniu przestrzenią lokalną. Praca skupia się na korzyściach z wprowadzenia budżetu partycypacyjnego, który jest wspólny dla władz i społeczności lokalnej. Przedstawia też zagrożenia dla tego narzędzia partycypacji społecznej, w tym jedno z największych, jakim jest słabnące zainteresowanie mieszkańców uczestnictwem w jego tworzeniu i realizacji. Główna hipoteza artykułu zakłada w tym wypadku, że najsilniej problem frekwencyjny związany z uczestnictwem ludności miejskiej w budżecie partycypacyjnym dotyka dużych miast, co potwierdza analiza funkcjonowania tego narzędzia w największych polskich miastach, w latach 2014-2018. W podsumowaniu wyników 
analizy, w artykule podkreślono, że budżet partycypacyjny w dużych polskich miastach nadal pozostaje narzędziem nie do końca ugruntowanym i skutecznym. Wymaga także kolejnych lat pracy władz lokalnych i samego społeczeństwa, aby stać się narzędziem bardziej upowszechnionym społecznie, tak w zakresie wiedzy o nim samym, jak i obywatelskiego uczestnictwa w jego tworzeniu i realizacji.

Słowa kluczowe: budżet, partycypacja, społeczność lokalna, zarządzanie lokalne, projekty miejskie, inwestycje lokalne

\section{The Functioning of and Challenges for Local Authorities Related to the Participatory Budget in Poland Exemplified by Largest Polish Cities}

Abstract

The article presents issues related to the participatory budget as fast-developing contemporary tool of residents' participation in local space management. It focuses on the benefits of the participatory budget shared by authorities and local communities. The article also presents threats to that vehicle of social participation, including one of the key ones, i.e. the weakening interest shown by residents in its creation and implementation. The main premise of the article in this case is that large cities are the most affected by the weak attendance of urban population in voting on the participatory budget, which is confirmed by the analysis of the functioning of the tool in question in Poland's largest cities in the period 2014-2018. In the summary of the results of the analysis, the article highlights the fact that the participatory budget in large Polish cities continues to be not fully established or effective. It also requires further years of work of local authorities and society itself to become more popular among the public, both in terms of knowledge about it and civic participation in its creation and implementation.

Keywords: budget, participation, local community, local and municipal management, local investment projects 